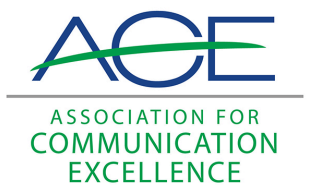

Journal of Applied Communications

\title{
A Review of Likeable Social Media: How to Delight Your Customers, Create an Irresistible Brand, and Be Generally Amazing on Facebook (and Other Social Networks)
}

Courtney D. Gibson

Follow this and additional works at: https://newprairiepress.org/jac c) (i) (2)

This work is licensed under a Creative Commons Attribution-Noncommercial-Share Alike 3.0 License.

\section{Recommended Citation}

Gibson, Courtney D. (2013) "A Review of Likeable Social Media: How to Delight Your Customers, Create an Irresistible Brand, and Be Generally Amazing on Facebook (and Other Social Networks)," Journal of Applied Communications: Vol. 97: Iss. 1. https://doi.org/10.4148/1051-0834.1099

This Review is brought to you for free and open access by New Prairie Press. It has been accepted for inclusion in Journal of Applied Communications by an authorized administrator of New Prairie Press. For more information, please contact cads@k-state.edu. 
A Review of Likeable Social Media: How to Delight Your Customers, Create an Irresistible Brand, and Be Generally Amazing on Facebook (and Other Social Networks)

Abstract

A Book Review of Likeable Social Media by D. Kerpen

Keywords

Book Review, Social Media, Networks 


\section{A Review of Likeable Social Media: How to Delight Your Customers, Create an Irre- sistible Brand, and Be Generally Amazing on Facebook (and Other Social Networks)}

\section{Courtney D. Gibson}

\section{Book Title}

Likeable Social Media: How to Delight Your Customers, Create an Irresistible Brand, and Be Generally Amazing on Facebook (and Other Social Networks)

\section{Author}

D. Kerpen

\section{Publisher}

New York, NY: McGraw-Hill

\section{Additional Information}

Paperback, 260 pages, \$20.00, ISBN: 978-0-07-176234-2

\section{Summary}

"Delight your customers, create an irresistible brand, and be generally amazing on Facebook." Sounds like any company's dream come true, but how does a company achieve such highly sought after accolades in today's competitive markets? Dave Kerpen, CEO of Likeable Media, a social media and word-of-mouth marketing firm based in New York City, seeks to help companies achieve just that in his book Likeable Social Media.

Likeable Social Media guides readers though 18 concepts Kerpen says will "guide you in your conceptualization, creation, and implementation of a social media plan" (p. 221). These 18 concepts are detailed individually in each of the book's chapters and are centered around four key principles: listen, be transparent, be responsive, and be likeable.

Social media connects to basic human nature in many ways, and Kerpen often relates his concepts to those human instincts. As humans, we simply want to be heard and be listened to. Social media provides people, who are consumers of numerous products, with an avenue of voicing their opinions, beliefs, and thoughts with the world. Many of the concepts Kerpen discusses in his book relate to listening to your consumers, because as he points out, "companies can no longer afford to ignore their customers' specific needs or complaints when the conversation can so easily be made public" (p. 14).

Throughout the book, Kerpen provides a variety of strategies on how to make customers of your product or service more than just customers. Engaging users, asking questions, telling and sharing stories, responding to comments, and inviting people to become your fans are just a few of the strategies companies can use to draw consumers into their social media experience. Companies should also be honest in their use of social media, and transparency can help customers establish trust. Creating a likeable vibe for your company is important and helps consumers connect to your company and products. 


\section{Review}

I found Likeable Social Media to be a very worthwhile read. It was well-written in an easy-toread manner and provides a thorough overview of social media marketing that anyone can understand and apply. Even though I consider myself to be a fairly avid user of social media, I learned a lot of new things about Facebook and how it can be used as a marketing tool (for example, I didn't know that Facebook had a "text-to-like" feature).

Kerpen does a nice job of introducing readers to each of the 18 concepts in his book. He often uses relatable analogies to make the world of social media less intimidating to readers, which I found to be a helpful way to make connections to the information being presented. One of the first analogies he uses refers to social media as the world's largest cocktail party, where "anyone can listen to others talking and join the conversation with anyone else about any topic of their choice" (p. 6). He says the qualities that would make you popular and likeable at a party - listening carefully, being transparent, being responsive, being authentic, and telling great stories - will also make your organization likeable on social networks. The analogies helped me view social media in a new way and helped me visualize the points he was trying to make.

Each chapter is also supported by several real-world examples of companies who have displayed that particular concept being used effectively (and in some cases, not so effectively). These examples helped me recognize how that concept should look in action, and put the concept into a tangible context. Many of the examples were from well-know companies such as Oreo, Omaha Steaks, Guinness, 1-800-Flowers, The Gap, and Dominos Pizza, so it was easy to connect to the examples, and some of them I was even familiar with from my own social media use.

Some of the concepts Kerpen discusses seem like they should be fairly intuitive, but many are things I - and I'm sure many others - have never thought about. Many times he asks readers to stop and think like a consumer, which I thought was helpful in understanding the impact of many of the concepts. Again, the examples and easy-to-read nature of the book drive these points home and make them very relatable to the reader.

While much of the book focuses on Facebook marketing, Kerpen often discusses how other social media outlets such as Twitter, YouTube and LinkedIn, can all be utilized, as well, making this a great resource for many people. Kerpen offers more of a best practices type approach to social media, like other notable social media resources, but the examples and writing style set this book apart from others I have read. I liked that this book was more relatable than some of the strategy-based social media resources that are commonly seen and offered a light-hearted, yet effective message about social media use. I didn't see many weaknesses with this book, as I thoroughly enjoyed the read and learned a lot in the process.

\section{Who Should Read This Book}

I think Kerpen's book would be a valuable tool to many readers. The concepts discussed in the book are applicable to any organization in any field. From small business owners who will be conducting their own social media marketing plan with one or two individuals to larger organizations who will have an entire office dedicated to social media marketing, Likeable Social Media has something to offer everyone, no matter what their level of experience with social media. For those with little experience using social media, Kerpen even includes an appendix called "A Refresher Guide to the Social Networks That Matter Most" to give them the basics of some of the more popular social media channels available. 
For the field of agricultural communications, Likeable Social Media would be a great resource when developing social media marketing plans for agricultural businesses and companies, as well as for helping them implement those plans. Marketing agricultural products can be a challenge, but using the basic principles detailed in Kerpen's book, social media can be a useful tool for the agricultural industry. 